\title{
ENTRE ESCOLAS E CULTURAS: TEORIA QUEER E MULTICULTURALISMO
}

Sandramor do Amaral Ferreira, Moda do Serviço Nacional de Aprendizagem Comercial do

$$
\text { Rio de Janeiro (SENAC) }
$$

sandramoramaral@gmail.com

Palavras-Chave: Educação, Arte, Teoria Queer, Gênero, Sexualidade

\section{INTRODUÇÃO}

A presente pesquisa teve como principal objetivo investigar como as identidades de gênero, sexualidade, masculinidade e raça são construídas na disciplina de artes em uma Escola Pública da rede municipal de Duque de Caxias - do Rio de Janeiro, e interagem com outras relações sociais que nelas se desenvolvem. Partimos do pressuposto que as discussões sobre gênero, sexualidades, masculinidades, raça, multiculturalidade e teoria queer podem contribuir para a diminuição da homofobia, da lesbofobia, da transfobia, do sexismo, do machismo, da misoginia, da discriminação, do racismo e da intolerância, ainda presentes em muitas de nossas escolas. A pesquisa constatou que a integração dessas propostas (multiculturalismo e teoria queer) em sala de aula pode contribuir para o reconhecimento e a valorização das múltiplas identidades presentes nas escolas

\section{METODOLOGIA}

Para atingirmos nosso objetivo adotamos os processos indicados pelo dispositivo da pesquisa-ação (BARBIER, 2004). Para obtermos uma compreensão do objeto investigado, utilizamos como instrumento e procedimentos de coleta de dados à observação participante e o registro no caderno etnográfico. Nesta perspectiva, foram realizadas observações participantes das dez aulas realizadas. Utilizamos o modelo qualitativo e a análise de conteúdo de Bardin (1995) como procedimento para organização, tratamento e análise dos dados coletados,

O referencial teórico deste trabalho está fundamentado na perspectiva pósestruturalista e na Teoria Queer, bem como nas propostas preconizadas pelo multiculturalismo como um corpo teórico de conhecimentos que visa o reconhecimento do outro e o diálogo entre os diferentes grupos culturais e sociais (CANDAU 2008; CANEN, 
2000; MOREIRA, 2002). Utilizamos a perspectiva de teóricos queer (BRIZTMAN, 1995, 2001; BUTLER, 1999, 2003; LOURO, 1997, 2000, 2003), principalmente aquelas referentes a questões ligadas a aspectos identitários.

\section{DESCRIÇÃO}

A pesquisa foi realizada em uma Escola Pública da rede municipal de Duque de Caxias - do Rio de Janeiro, em minha própria sala de aula durante o ano de 2016. Os dados apresentados foram gerados nas interações em sala de aula, nas observações do cotidiano da escola, e em entrevistas ou conversas com alunos/as da escola. Os dados apresentados foram gerados nas interações em sala de aula, nas observações do cotidiano da escola, e em entrevistas semi-estruturadas com alunos/as da escola.

\section{CONSIDERAÇÕES FINAIS}

A análise dos resultados permitiu perceber a importância da realização de um trabalho sistemático e contínuo que relacione as discussões sobre o conhecimento disciplinar às questões abordadas no estudo, de modo a produzir novos discursos e propostas alternativas por parte de professores e estudantes. A pesquisa constatou que é possível caminhar para além da denúncia e partir para anúncios que se concretizem em ações e reflexões desestabilizadoras dos discursos colonizadores e heteronormativos.

\section{REFERÊNCIAS}

BARDIN, L. Análise de conteúdo. Lisboa: Edições 701995.

BARBIER, R. A Pesquisa-ação. Brasília: Liber Livro, 2004.

BRITZMAN, Deborah. Is there a queer pedagogy? Or stop reading straight. Educational Theory, Illinois, v.45, n. 2, p. 151-166, primavera 1995.

BUTLER, J. Corpos que pensam: sobre os limites discursivos do sexo. In: LOURO, G. L. (Org.) O Corpo educado: pedagogia da sexualidade. Tradução Tomaz Tadeu da silva. Belo Horizonte: Autêntica, 1999, p. 151-72.

Problemas de gênero. Feminismo e subversão da identidade. Rio de Janeiro: Civilização Brasileira, 2003.

CANDAU, V. M. Multiculturalismo e Educação: desafios para a prática pedagógica. In: MOREIRA, A. F. B.; CANDAU, V. M. (Org.). Multiculturalismo: diferenças culturais e práticas pedagógicas. Petrópolis: Vozes, p. 13-37, 2008.

CANEN, A. Educação multicultural, identidade nacional e pluralidade cultural: tensões e implicações curriculares. Cadernos de Pesquisa, n.111, p. 135-149, 2000. 
MOREIRA, A. F. Currículo, diferença cultural e diálogo. Educação \& Sociedade, Campinas, ano XXIII, n.79, p. 53-83, 2002.

LOURO, Guacira Lopes. Gênero, sexualidade e Educação: uma perspectiva pósestruturalista. São Paulo:Vozes, 1997.

LOURO, Guacira Lopes (org.). O corpo educado: pedagogias da sexualidade. Belo Horizonte: Autêntica, 2000. p. 151-172.

Problemas de gênero: feminismo e subversão da identidade. Rio de Janeiro: Civilização Brasileira, 2003. 